\title{
Application of Micro Video Teaching Resources in College English Teaching
}

\author{
Ying Wang
}

Teaching and Research Institute of Foreign Languages, Bohai University, Jinzhou, 121013, China

664555326@qq.com

Keywords: micro video; teaching resources; college English teaching; micro learning; application strategies

\begin{abstract}
Micro video teaching resources improve the students' English communication skills, and it causes the student to place oneself in authentic English language environment, create a lively atmosphere of English learning. Is studied in this paper, based on the micro study, micro video teaching mode and micro video resources in college English teaching, puts forward the application of micro video teaching resources in college English teaching strategy. Specific strategies include: micro video clips to choose should help improve the students' comprehensive ability, micro video teaching resources design should pay attention to the teaching process, the micro video design should reflect to the students as the center of guiding ideology, adhere to the open generative strategy of video production. Micro video teaching resources to meet the demand of the information age of college English teaching, to improve college English teaching and English application ability, etc. is of great significance.
\end{abstract}

\section{Introduction}

With the development of education informatization, based on the digital platform based on network and multimedia media new mode of modern education, has already penetrated into each aspect of the traditional teaching, plays a huge boost in education reform. Micro video was transmitted through the mobile terminal equipment and the exchange of a new form of video. As the main medium of visual, is regarded as the media of information resources, also known as "micro video resources". Micro video usually refers to short for 30 seconds, long is no more than 20 minutes of video, and wide-ranging, presenting forms, including small segments of film, record video, DV, video and advertising, etc., and can be through a variety of video terminals the floorboard of the video recording or playback of video clips." Short, fast, pure", the audience is wide, strong randomness is the biggest characteristic of micro video. From the perspective of education and teaching, the video is to point to contain teaching target, teaching content, teaching activities, teaching resources and teaching evaluation and so on various elements of video resources, is the main presentation of the course, is also the main process of micro course learning activities in the resources [1]

The teaching aim of college English is to cultivate the students' English comprehensive application ability, especially listening and speaking skills, to make them in the future study, work and social activities can communicate effectively in English, at the same time to improve their ability of autonomous learning, improve the comprehensive cultural quality, to meet the need of social development in our country and international communication. In the cultivation of college English listening and speaking ability and autonomous learning ability in the teaching process, the micro video resources have special effects. Micro video with voice, image, and a wealth of information, provide English teaching with the three-dimensional environment in which to learn, can quickly attracted students into the learning state, increase efficiency of the teaching and is loved by the masses of students teaching means [2]. 


\section{Micro Learning}

Micro study is the use of mobile communication technology to realize two-way communication way of learning, learning can be implemented any time and any place. Micro miniature learning content, carried by the media is based on the content of the practical short block to render the learning content and organize learning activities, learning stressed in the limited time is relatively short, loosely connected, self-contained knowledge content or module, such as mobile phone, PDA handheld mobile terminal as the carrier. Therefore, need to micro media to present the content of the mini, in a variety of mobile terminal to carry miniature course, and mobile communication tools to implement and the micro study of interactive communication. Miniature learning process framework is shown in Fig.1 [3].

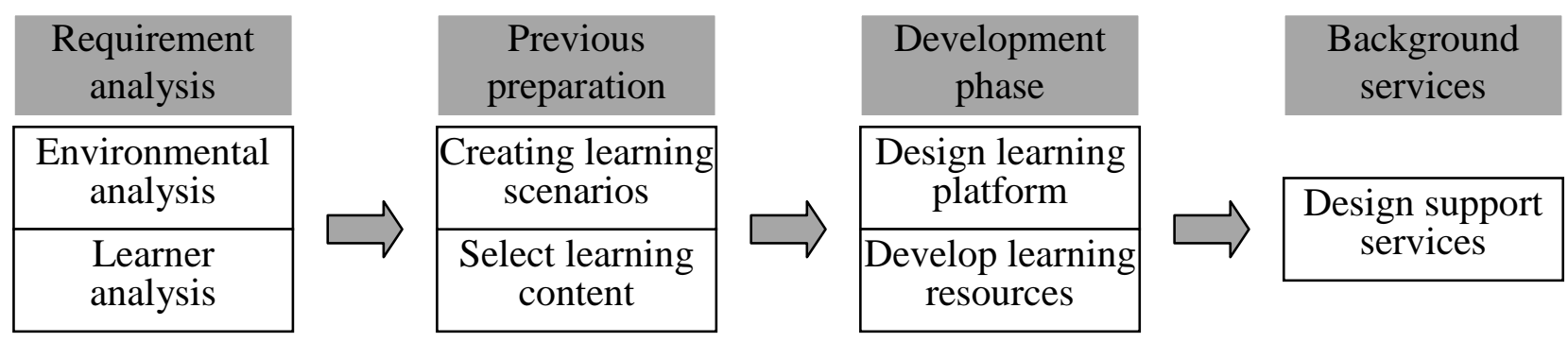

Fig. 1. Micro learning process framework

The micro study has the following characteristics: (1) the learning content scattered one-sided. Miniature requires learning content is small fragments, small units of information to accept, store, and the circulation of contents; (2) the learning time is short and scattered. The micro learning requires a relatively short time and flexible distribution in space time of daily life; (3) the learning media diversity. Micro medium to learn fully adopted the advanced digital media technology, to meet the needs of a wide variety of; (4) individualized learning. Micro study using a variety of media, learning time, content, method and place are choices and decisions by the learners themselves.

\section{Micro Video Resources Teaching Mode}

Learning mode is to assume that allows individuals to achieve the best learning method. The thought of "learning mode" originated in the $1970 \mathrm{~s}$, gaining popularity in recent years. This theory offers teachers should evaluate the students' learning mode, and makes the classroom teaching method can best suited to each student's learning mode. Micro video based on multimedia teaching resources make complex knowledge more visual and intuitive, better able to arouse interest in learning, help students to explore independently. The micro video teaching resources in the traditional classroom teaching, can give full play to the micro video multimedia technology advantage. Teachers can be used to guide for students' extracurricular autonomous learning and solving problems in students in the use of micro video teaching resources. A combination of both made strengths of the micro video assisted teaching, and improve the quality of the teachers' classroom teaching. Micro video resources teaching mode is shown in Fig. 2 [4].

\section{Micro Video Resources and College English Teaching}

Micro video resources has changed the college English teaching model, provided a new teaching method for college English teaching, and improved the students' language application ability. Specific purpose [5-8] below:

(1) Micro video teaching resources has improved the students' English communication skills. The traditional college English teaching, students in a passive position, teachers use class time to read the words, grammar and translation of the text. In order to cope with the exam, students force by using the method of rote memory. But English as a communication tool, in actual need English 
communication environment situation, most of the students understand the cultural background, also can't use oral English to communicate. In recent years, aimed at improving students' communicative ability of communicative teaching method in college English teaching advocated, English teaching should be dominated by communication, combined with the actual situation for the students to create the opportunity to communicate, reflect the students' main body role. Micro video teaching mode, combined with multimedia technology such as image, audio and subtitles, students during watch the video at the same time, in the context of a simulation study pronunciation, improve the oral English standard, stimulate interest in learning English.

(2) The micro video teaching resources make the students in the real English language environment. Language learning environment is a broad concept, from the broad sense, including the learners in the process of learning a language of the social, political, economic and cultural environment. In a narrow sense, including places of learning a language, learning tools and learning media. Language is closely connected with English learning environment, a good language environment is the basic condition of college students to learn English well, is the important foundation of improving learners' English level. Learner language environment, direct method, the efficiency of learning, and decides to continue learning interest and direction, effectively choose language learning environment, create the most favorable and the most suitable for their own environment, is the key to the learners can achieve learning effect. Micro video teaching resources, English film material show in the video content are refined processing, making English language part of the environment is the most close to life, and with the relevant European and American culture, let the students watch at the same time not only increase the vocabulary ability, exercise the ability of English listening and speaking, also a lot of rich cultural knowledge.

(3) Micro video teaching resources could build a lively English learning atmosphere. The traditional classroom teaching in English language learning from the development and changes of real life, affect the normal language communication activities, students learned is "mute" English. As information technology era of English teachers, should change the former teaching ideas, using various means to build English learning atmosphere, as much as possible for students to create more opportunities for using English. With the emergence of micro video teaching resources, teachers can easily get rich content in the teaching activities of the English video expansion, including the us and European news broadcasts, television ads, and learning materials, such as various forms of teaching resources, according to the students' learning situation and actual needs, teachers' union course selection of English teaching content of different video clips, create a relaxed and lively English classroom atmosphere.

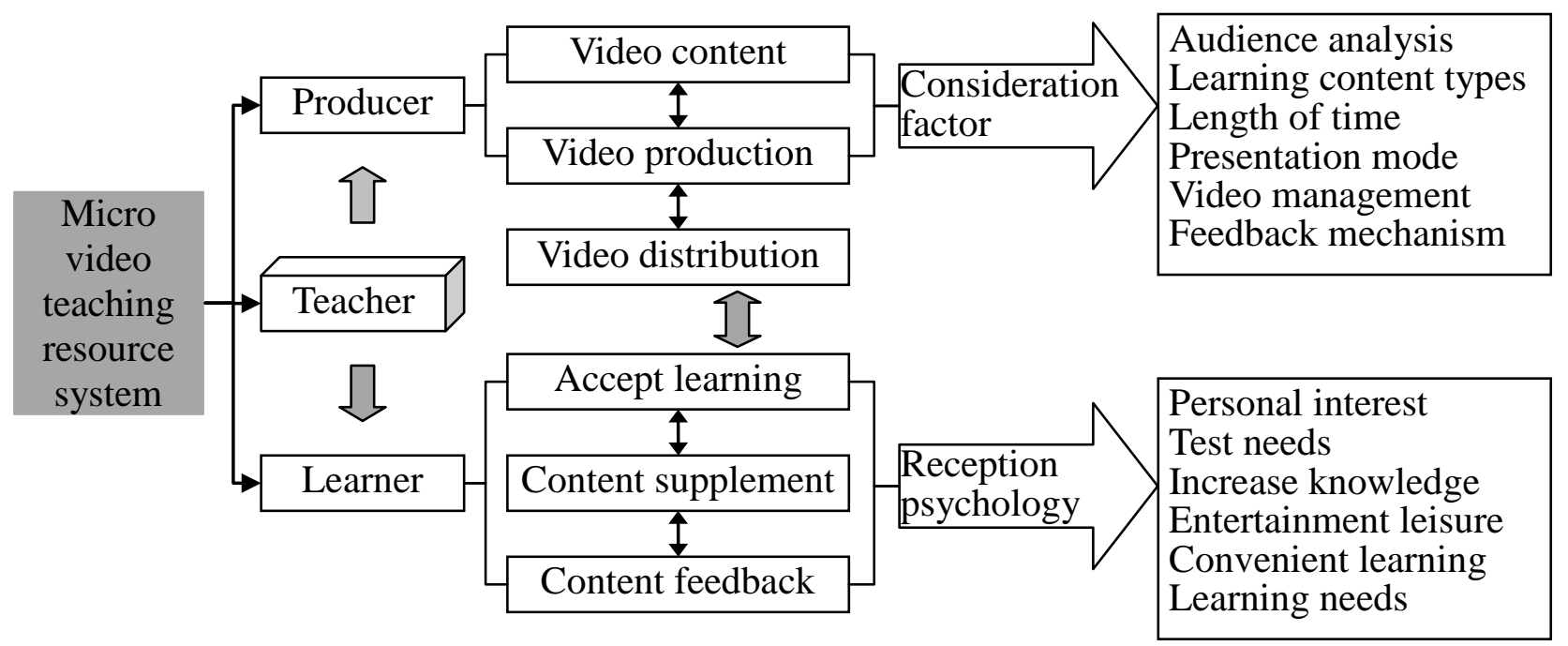

Fig. 2. Micro video resource teaching mode 


\section{Application Strategies of Micro Video Teaching Resources in College English Teaching}

According to the characteristics of the college English teaching, combining the micro video teaching and research present situation, proposed the application of micro video teaching resources in college English teaching strategy [9-12] as follows:

(1) The micro video clips to choose should help improve students' comprehensive ability. College English teaching purpose is to make students have in listening, speaking, reading, writing, translating and so on aspects of the comprehensive application ability. Therefore, the teacher selected micro video should be related to the teaching material content background knowledge and cultural customs and habits, or the practical spoken dialogue scenes in different scenarios. Select source can be a movie clips, current news and documentaries, also can be entertainment information, to display the cultural background of English from different angles. In this way can make students better understand the teaching material, expand their horizons, enrich their knowledge, involved in interesting audio-visual materials to study the teaching material of words and related cultural knowledge, and master certain practical oral words and phrases, etc.

(2) The micro video teaching resources design should pay attention to the teaching process. Before making micro video resources through the text, images and video import, make the content more clearly, by importing the pertinent course material, makes the students at the same time of learning knowledge, exercise the eyes, ears, mouth and brain and ability, and enhance the interest in learning English, to facilitate the understanding of heavy difficult knowledge points. Present in class can consolidate teaching difficult point, increase the density and width of the classroom teaching and conducive to visualize the abstract knowledge teaching. Micro video teaching resources because of its short, facilitate students in the class under review, consolidate knowledge, at the same time through the micro video operation reduce the homework after class. In the process of classroom interaction, students' writing level also can get a better development, using interactive video teaching resources, improve the English writing skills. Rational utilization of the micro video in class can make the students to study in the context of real knowledge, deepen the mastery of knowledge, improved the ability of flexible use.

(3) Micro video design should reflect the guiding ideology of the student-centered. Micro video based on a study subject core organized activities, not just simply integrating technology into the curriculum, it is more important is to have out of social learning activity back to the real life, will be artificially isolated knowledge source back to the real life, will study the passive to accept a single way to study way of rich and colorful. Micro video classes tend to be short, the teaching material is small, has a great deal of flexibility, the design of the related activities in general and the reality, not just let students to extract knowledge, but rather to encourage students to a higher level of thinking, in the process of specific activities, the students not only learn the knowledge of this course, and the other related discipline knowledge. Teaching education is objective existence, in micro video, teachers always try to set some associated with realistic problem scenarios to infect students, for students' emotion has a positive impact, and attract the attention of students, encourage students to complete assigned tasks and to cultivate students ability to solve practical problems.

(4) Micro video production and opening generative strategy. Open production refers to the micro video production main body is not limited to teachers, students inspired by teachers to make micro video content, you can change and supplement, regenerated with students on a topic or knowledge of personalized video, and upload them to a particular area of the micro resources, for other learners study and comment, formed about each video learning communities, this not only enriched the micro video type and style, also can improve the enthusiasm of students to use micro video resources to inspire students' intrinsic motivation, learning to overcome the defects of lack of depth of ubiquitous learning. Students' intrinsic motivation and self-efficacy affect students on micro video resources is useful to sexy as the most significant factors, and to participate in the video creation interest sex will not only help students useful sexy, also is good for students to ease and pleasure perception sexy. 


\section{Conclusion}

New college English teaching mode should take modern information technology, especially network technology, as the support, which can make the teaching and learning of English in a certain extent, not limited by time and place, the direction of individualized and autonomous learning. New English teaching mode should reflect the principle of combining practical, informative and interesting teaching, is helpful to arouse the enthusiasm of teachers and students two aspects, especially mainly to reflect the subject status of students and teachers in a leading role in the process of teaching. Micro video teaching resources meet the demand of the information age of college English teaching and it has a great significance in improving college English teaching and English application ability and so on.

\section{References}

[1] J. T. Chen, M. Wang, J. M. Zhan, D. Kang, "Research on design strategy of micro video teaching content," China CIO News, vol. 28, no. 5, pp. 157-158, 2015.

[2] J. P. Mi, "Application of micro video in college English teaching," Modern Vocational Education, vol. 1, no. 22, pp. 46-47, 2015.

[3] C. Liu, "Summary of micro study," Software Guide, vol. 4, no. 3, pp. 6-8, 2011.

[4] J. Zheng, Y. N. Wang, K. L. Wang, Y. Bai, "Study on the design of micro learning video," China Educational Technology, vol. 33, no. 4, pp. 21-25, 2012.

[5] L. Zhang, "Research and application of micro teaching video resources in university English teaching," Electronic Test, vol. 21, no. 14, pp. 149-150, 2014.

[6] T. Ma, "Discussion on the importance of communication in English teaching and its application," Foreign Language World, vol. 22, no. 1, pp. 49-53, 2001.

[7] X. Xin, "On the role of language environment in English learning," Intelligence, vol. 11, no. 32, pp. 162, 2011.

[8] X. J. Pan, "On the construction of the atmosphere of English learning," Jiangxi Education, vol. 55, no. 20, pp. 25-26, 2004.

[9] Y. X. Liu, "The role of video in college English teaching," China Adult Education, vol. 20, no. 8, pp. 120-121, 2011.

[10] G. Zhou, "A preliminary study on the application of micro video teaching resources in College English Teaching," Essays in a hundred, vol. 10, no. 7, pp. 22-23, 2015.

[11] P. Chen, S. Q. Chen, "The development and management strategies of micro video curriculum resources under the perspective of technology acceptance," Journal of Yantai Vocational College, vol. 21, no. 2, pp. 82-85, 2015.

[12] X. F. Guo, "Micro-lecture Video Resources Design Strategies," The Guide of Science \& Education, vol. 5, no. 12, pp. 129-130, 2013. 